Biospecies Vol. 11 No. 1, January 2018

\title{
Molecular Characteristics of Giant Gourami from Ciamis and Banyumas
}

\section{Agus NURYANTO and Dian BHAGAWATI}

Faculty of Biology, Universitas Jenderal Soedirman

Dr. Suparno Street No. 63 Grendeng, Purwokerto 52122, Indonesia

E-mail: anuryanto2003@yahoo.com

\begin{abstract}
Abstract. Giant gourami has been widely cultivated across Java Island, including in Banyumas and Ciamis Regencies. However, information genetic characters of both populations were not available. Therefore, this study aims to evaluate molecular characteristics of giant gourami from Ciamis and Banyumas. A purposive random sampling was done Molecular characterization was performed using randomly amplified polymorphic DNA. Molecular data were analyzed statisticaly. Both populations were genetically different and they have high genetic diversity within population. Based on the high genetic diversity of giant gourami from Ciamis and Banyumas populations, it would be very good to crossbreed between those both to produce high quality offspring.
\end{abstract}

Keywords: Banyumas, Ciamis, Giant Gourami, Morphology, RAPD

\section{INTRODUCTION}

Low genetic quality of cultivated giant gourami fish has long time been noted as one of the most common obstacle in farming of this species. This might results in low quality offspring and leads to low growth rate as well as low resistance to various diseases. Previous studies had proved a positive corelation between genetic constituent and either resistance (Kusbiyanto et al., 2016; Kurtz et al., 2004, 2006: Wegner et al., 2006; Consuegra \& Leaniz, 2008; Rakus et al., 2009; Aryanto et al., 2015; Azis et al., 2015) or growth performance of wide range of fish species (Kang et al., 2002; Tao and Boulding, 2003; Blanck et al., 2009).

There are several techniques to identify the genetic quality of the broodstocks of giant gourami, starting from a simplest way through morphological characterization up to a sophisticated one with molecular characterization. Mayr and Ashlock (1991) stated that morphological characters are generally reflect most of genetic traits. Previous studies proved that different growth performance among individuals possitively related to their genetic constituent which lead to different morphological characteristics on fish species (Gela et al., 2010; Kocour et al., 2010; Kohlmann et al., 2010; Lajbner et al., 2010; Kocour and Kohlmann 2011). Moreover, morphological divergences among giant gourami strains (Setjaningsih et al., 2007) as well as among local populations (Bhagawati and Abulias (2007) had been reported. Kusmini et al. (2000) noted that each strain have their own growth potential, which lead to different morphological characteristics of those giant gourami. However, those studies were only done among different strains; in populations from Tasikmalaya, Purbalingga, 
and Blitar; and also used morphological and isozyme data. Yet, study on morphological and molecular characteristics of giant gourami populations from Ciamis and Banyumas using DNA marker was unavailable. Therefore, examinination of giant gourami from Ciamis and Banyumas either morphologically or molecular become a prerequisite in providing scientific data for giant gourami cultivation and breeding efforts.

Randomly amplified polymorphic DNA (RAPD) is molecular markers that commonly used in genetic differentiation studies among populations or population genetic study. This marker were developed through DNA amplification using short arbitrary primer with length of 10 bases (Penner et al., 1993). This method produce a lot of DNA fragments which most of them are specific for certain individual (Welsh and McClelland, 1990; Williams et al., 1990). This means that RAPD markers are highly variable. This marker had widely been used in population genetic of various animals (Klinbunga et al., 2001; Rego et al., 2002; Holmes et al., 2004). Moreover, RAPD marker showed high genetic variation within population (Baozhong et al., 2006). This marker is also useful in species delimitation (Marin et al., 2007) due to its high polymorphism. So, it is expected that RAPD marker can be used as a reliable molecular marker to characterize giant gourami broodstocks from Ciamis and Banyumas.

Here we characterized giant gourami broodstocks populations from Ciamis and Banyumas using morphological characters and
RAPD markers aims to evaluate the morphology and molecular characteristics of giant gourami populations from Ciamis and Banyumas.

\section{METHODS}

\section{Samples Collection}

Current study applied a survey method with purposive random sampling. Fish samples were collected from Ciamis and Banyumas Regencies. Samples for morphological observation were divided into two different groups which is consisted of 30 female and 30 male individuals for each sampling site, respectively. However, molecular characterization was performed on 27 individuals from Ciamis (15 females and 12 males) and on 30 individuals from Banyumas (15 females and 15 males).

\section{Morphological Characterization}

Morphological characters were divided into two different groups, i.e. morphometrics (measure) and meristics (count) characters. The parameters for morphometric measures were standart length, head length relative to standart length, and body heigth relative to standart length. This ratio values were selected to minimize the bias on the data due to different ages between the used broodstocks and to increase scientific value of the data. Meristics characters was examined refers to Saanin (1968) and Kottelat et al. (1993). The parameter of meristic characters were spines and fin rays on dorsal fin (D), anal fin (A), 
ventral fin $(\mathrm{V})$, and fin rays on pectoral fin $(\mathrm{P})$, and also scales number on linea lateralis (LL).

\section{DNA Isolation and Amplification}

Total genomic DNA was isolated using Chelex methods (Walsh et al., 1991) with small modification in incubation duration. The used molecular marker was randomly amplified polymorphic DNA (RAPD). This marker was amplified using two primers, i.e. OPA 07 and OPA 09. The PCR reaction has a total volume of $25 \mu \mathrm{l}$. The PCR mixtures consisted of $1 \mathrm{x}$ PCR buffer, $0.16 \mathrm{mM}$ of each dNTPs, 0.4 pmol of each primer, $3 \mathrm{U}$ of DNA Taq polymerase, and template DNA of $1.5 \mu \mathrm{l}$. Final volume of $25 \mu 1$ was adjusted by adding of ultrapure water $\left(\mathrm{ddH}_{2} \mathrm{O}\right)$ as much as of $17.85 \mu 1$. RAPD markers were developed through DNA template amplification in PeqStar thermocycler (Thermosientific). Thermal conditions were as follow. Predenaturation at temperature of $94^{\circ} \mathrm{C}$ for 3 minutes and continued with 35 cycles which was consisted of denaturation at $94^{\circ} \mathrm{C}$ for 1 minute, 2 minutes of primer annealing at $40^{\circ} \mathrm{C}$ and extension at $72^{\circ} \mathrm{C}$ for 1 minute. Final extension was performed for 10 minutes at $72^{\circ} \mathrm{C}$. Amplicons were migrated in $1 \%$ agarose gel and visualized over UV-light transiluminator after stained in ethidium bromide (Nuryanto and Susanto, 2010)

\section{Data Analysis}

Morpholigical data were analysed descriptively and compared them to standard characters as described in Saanin (1968) and Kottelat et al. (1993) determinatin keys. Gene or haplotype and locus diversity were analyzed statistically with the help of arlequin software version 2.0. Genetic differetiation between Ciamis and Banyumas populations was analyzed statisticaly using analysis of molecular variance (AMOVA) as implemented in arlequin software version 2.0 (Schneider $e t$ al., 2000). In this case, RAPD markers were treated as RFLP markers. Therefore, molecular analysis was performed after transforming qualitative data (band pattern) into quantitative binary data $(0: 1 ; 0$ means no RAPD marker appear in agarose gel and 1 means RAPD markers are present in agarose gel).

\section{RESULTS AND DISCUSSIONS}

Morphological examination of giant gourami populations from Ciamis and Banyumas Regencies showed that both populations has similar coloration (Figure 1). Deeper observation on the other morphological characters also showed that both populations have similar morphometric (head length ratio and body heigth ratio) and meristic (such as fin rays and spines number, and also scales number in lateral lines) characters. Detailed data on morphological characteristics of both giant gourami populations are summarized in Table 1. 


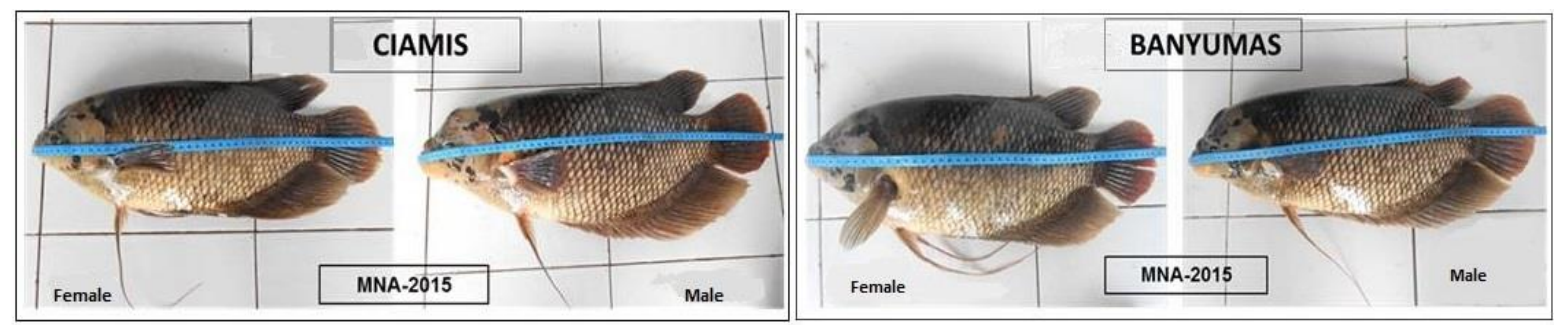

Figure 1. Male and female broodstocks of giant gourami from Ciamis and Banyumas Regencies

Our data proved that there was no morphological divergences among both populations. In other words, giant gourami from Ciamis and Banyumas have similar morphology. Refering the morphological characteristics of our samples to those described in Kottelat et al. (1993) and Saanin (1968) for Osphronemus gouramy Lacapede, it showed that our samples have similar morphology to the described species. Hence, we were confident to place our giant gourami samples from Ciamis and Banyumas into single species, i.e. O. goramy Lacepede, 1801. We were confidence to place our samples into O. goramy because according to morphological species concept as describe by Claridge et al. (1997), individuals with similar morphology could be delimited into a single species.

Table 1. Morphological characteristics of giant gourami broodstocks from Ciamis and Banyumas Regencies

\begin{tabular}{lcc}
\hline \multicolumn{1}{c}{ Morphology } & Ciamis Population & Banyumas Population \\
\hline Dorsal fin (D) & D.XII-XIII.11-13 & D.XII-XIII.11-13 \\
Pectoral fin (P) & P.2.13-14 & P.2.13-14 \\
Ventral fin (V) & V.I.5 & V.I.5 \\
Anal fin (A) & A.IX-XI.16-22. & A.IX-XI.16-22. \\
Scales on lateral line (LL) & $31-33$ & $31-33$ \\
Standard length & $51-61$ & $48.5-57$ \\
Head length ratio & $0.196-0.236$ & $0.206-0.218$ \\
Body heigth ratio & $0.364-0.402$ & $0.365-0.396$ \\
\hline
\end{tabular}

It was not clear whether morphological similarity between Ciamis and Banyumas giant gourami populations is positively correlated with their genetic constituent. To overcome this problem and figure out molecular characteristics of both giant gourami populations, we characterized and compared those both populations molecularly using amplified polymorphic DNA (RAPD) marker. 
Table 2. Pairwise $\Phi_{\mathrm{st}}$-values between giant gourami broodstocks populations $(\mathrm{p}=0.0000)$

\begin{tabular}{lcc}
\hline \multicolumn{1}{c}{ Population } & Ciamis & Banyumas \\
\hline Ciamis & - & \\
Banyumas & $0.042^{* * * *}$ & - \\
\hline
\end{tabular}

remarks:

$$
{ }^{*}=0.05 \geq p \geq 0.01,{ }^{* *}=0.01>p \geq 0.001,{ }^{* * *}=p<0.001
$$

Pairwise $\Phi_{\text {st }}$ comparison proved that giant gourami populations from Ciamis and Banyumas was genetically significant different (Table 2). Our result similar to the result of Rahman (2014) on giant gourami populations from Parung (Bogor), Tasikmalaya, Banyumas, and Tulung Agung (East Java). On that study, Rahman (2014) also observed significant genetic differences among populations. Nugroho et al. (2006), also reported a genetic sigificant different among Giant gourami populations from Ciamis and Banyumas are genetically different, but they have similar morphology. This is could be due to that as cultivated population, giant gourami from Ciamis and Banyumas are treated similarly and their environments are manipulated in a similar manner. These treatments might lead to a similar phenotype between them, though they are genetically different. According to Kussell and Leibler (2005), Whitham et al. (2003), and Roger et al. (2002), phenotype is a result of combination effect of genetic component and environment. Consequently, it is not surprising that genetically different individulas that live
Neolissochilus (kancra) populations from West Java. These similarities could be due to that Our, Rahman (2014), and Nugroho et al. (2006) studies used similar genetic markers. Additional information obtained from our study and those studies from Rahman (2014) and Nugrogo et al. (2006) proved that RAPD is a reliable marker for genetic differentiation study among populations (population genetic study).

in similar environment and treated in similar manner might have similar phenotype or morphology.

We were also analyzed genetic diversity within each population to support breeding and cultivation efforts of giant gourami. Genetic diversity analysis within population showed that Ciamis poulation has gene diversity (h) of 0.987 and for Banyumas population was of 0.929 . locus diversity $(\pi)$ value was of $13.268 \%$ for Ciamis population and for Banyumas population was of $12.389 \%$. Detailed information about genetic diversity of both populations were presented in Table 3 .

Table 3. Number of sample $(\mathrm{N})$, allele number (nhp), gene diversity $(h)$, and locus diversity $(\pi)$ of each giant gourami populations from Ciamis and Banyumas

\begin{tabular}{|l|c|c|c|c|}
\hline \multicolumn{1}{|c|}{ Population } & $\mathrm{N}$ & $\mathrm{nhp}$ & $\mathrm{h}$ & $\pi(\%)$ \\
\hline Ciamis & 27 & 24 & $0.987 \pm 0.015$ & $13.268 \pm 7.701$ \\
\hline Banyumas & 30 & 21 & $0.929 \pm 0.039$ & $12.389 \pm 7.235$ \\
\hline
\end{tabular}


Those diversity values proved that both populations has high genetic diversity. Our result similar to a study from Sari et al. (2014) on Jepang, Bluesafir, and Soang strains and also to study from Nugroho (2014) who studied genetic diversity within Blusafir, Paris, and Soang giant gourami strain populations. These similarities could be due to that we used similar genetic marker, that was RAPD markers. According to our study and the study from Sari et al. (2014) and Nugroho (2014), it seem that high genetic diversity is a common phenomena in giant gourami population based on RAPD marker. High RAPD diversity within population were also observed in other fish species (Mulyasari et al., 2010; Geertjes et $a l ., 2004)$ and also other animal groups, such as in Polymesoda erosa (Nuryanto and Susanto, 2010), oyster (Klinbunga et al., 2001), mussels (Rego et al., 2002), abalone (Huang et al., 2000), zebra and quangga mussels (Stepien et al., 2002), and Abra tenuis (Holmes et al., 2004), and in scallop (Baozhong et al., 2005).

High genetic diversity in giant gourami populations from Ciamis and Banyumas was rather surprising since we used cultivated populations which are usually under high selection pressures from fisheries activities. It is common phenomena that selection pressure on certain agronomic character on cultivated organisms will result in low genetic diversity. In our case, it is suggested that fish farmer from both regions select their broodstocks randomly to avoid that their broodstocks were resulted from inbreeding process which might leads to low genetic diversity. Therefore, we observed high genetic diversity in giant gourami populations from Ciamis and Banyumas.

High genetic diversity on giant gourami populations from Ciamis and Banyumas in our study is advantageous for cultivation of that species because high genetic diversity might increase the resistance of giant gourami to various diseases and good for adaptation. Previous studies from Hughes and Stachowicz (2004) and Tarpy (2003) had proven that genetic diversity is an important component for population resistant. Moreover, other studies also observed that high genetic diversity is vital for adaptation to environemntal condition (O'brien, 1994) and population fitness (Reed and Frankham, 2003). This research provide scientific information on morphology and molecular characteristics of giant gourami from different locations. This informations are vital for management of giant gourami broodstocks and also for cultivation and breeding efforts of giant gourami, especially for the populations from Ciamis and Banyumas. Both broodstacks populations from Ciamis and Banyumas can be crossbrded to each other to produce qualified offspring because each population will contribute their high genetic constituent diversity to their offspring during breeding process to increase the quality of the offspring. 


\section{CONCLUSION}

Giant gourami broodstocks populations from Ciamis and Banyumas have similar morphological characteristics. Those characteristics fit well with the description of Osphronemus giant gourami Lac. However, both populations are genetically significant different.

\section{AKCNOWLEDGEMENTS}

We would like to deliver our special thank to the Directorate of Research and Public Services, Ministry of Research, Technology, and Higher Education which provided funding through the Hibah Bersaing 2015 scheme; Research and Public Service Institute of Unsoed and the Dean of Biology Faculty of Unsoed which always provide support to us for doing reasearch, fish farmers in Ciamis and Banyumas Regencies for their cooperations, and also students who help during laboratory works. Our gratitude is also delivered Muh Nadjmi Abulias (RIP) dan Slamet Priyanto (RIP) who start this study excellently. High appreciation is also delivered to editor and reviewer who gave valuable advises and corrections to enrich this manuscript.

\section{REFERENCES}

Aryanto, D., Hayuningtyas, E.P., \& Syahputra, K. (2015). Hubungan antara keberadaan gen Major histocompatibility complex class II (MHC-II) ketahanan terhadap penyakit, dan pertumbuhan pada populasi ikan mas Ras Rajadanu. Jurnal Riset Akuakultur, 10(4), 461 - 469.
Azis, Alimuddin, Sukenda, \& Junior, M.Z. (2015). Identifikasi kandidat MHC I pada ikan lele (Clarias sp.) tahan infeksi Aeromonas hydrophila. Jurnal Riset Akuakultur, 10(2), 261-269.

Baozhong, L., Feng, Y., Bo, D., \& Jianhai, X. (2006). The comparison between allozyme and RAPD makers for the population genetic structure analysis of scallop Chlamys farreri. Chinese Journal of Oceanology and Limnology, 24(3), 295-299.

Bhagawati, D. \& Abulias, M.N. (2007). Karakter Meristik Bilateral dan Polimorfisme Isozim Sebagai Dasar Seleksi Untuk Memproduksi Benih Gurami Unggul. Laporan Penelitian (Tidak dipublikasikan). Purwokerto: LPPM Unsoed.

Blanck, D.V., Gasparino, E., Ribeiro, R.P., \& Marques, D.S. (2009). Polymorphism in the GH1-PstI gene associated to corporal characteristics in Nile tilapia strains. Pesq Agropec Bras, 44(6), 599-604.

Claridge, M.F., Dawah, H.A., \& Wilson, M.R. (1997). Species: The Unit of Biodiversity. London: Chapman and Hall.

Consuegra, S. \& de Leaniz, C.G. (2008). MHC-mediated mate choice increases parasite resitance in salmon. Proceedings of the Royal Society B, 275(1641), 1397-1403.

Gela, D., Kocour, M., Flajshans, M., Rodina, M., \& Linhart, O. (2010). Comparison of performance of genome manipulated and standard tench, Tinca tinca (L.), groups under pond management conditions. Rev Fish Biol Fish, 20, 301-306.

Geertjes, G.J., Postema, J., Kamping, A., van Delden, W., Videler, J.J., \& van de Zande, L. (2004). Allozymes and RAPDs detect little genetic population substructuring in the Caribbean stoplight parrotfish Sparisoma viride. Marine Ecology Progress Series, 279: 225-235.

Holmes, S.P., Dekker, R., \& Williams, I.D. (2004). Population dynamics and genetic differentiation in the bivalve mollusc Abra tenuis: aplanic dispersal. Marine Ecology Progress Series, 268: 131-140. 
Huang, B.X., Peakall, R., \& Hanna, P.J. (2000). Analysis of genetic structure of black lip abalone (Haliotis rubra) populations using RAPD, mini satellite and micro satellite markers. Marine Biology, 136, 207-216.

Hughes, A.R. \& Stachowicz, J.J. (2004). Genetic diversity enhances the resistance of a seagrass ecosystem to disturbance. PNAS, 101(24), 8998-9002.

Kang, J.H., Lee, S.J., Park, S.R., \& Ryu, H.Y. (2002). DNA polymorphism in the growth gene and its association with weight in olive flounder Paralichthys olivaceus. Fisheries Science, 68, 494498.

Klinbunga, S., Ampayup, P., Tassanakajon, A., Jarayabhand, P., \& Yoosukh, W. (2001). Genetic diversity and molecular markers of cupped oysters (genera Crassostrea, Caccostrea, and Striostrea) in Thailand revealed by randomly amplified polymorphic DNA analysis. Marine Biotechnology, 3, 133-144.

Kocour, M., Gela, D., Rodina, M., \& Flajshans, M. (2010). Performance of different tench, Tinca tinca (L.), groups under semi-intensive pond conditions: it is worth establishing a coordinated breeding program. Rev Fish Biol Fish, 20, 345-355.

Kocour, M. \& Kohlmann, K. (2011). Growth hormone gene polymorphisms in tench, Tinca tinca L. Aquaculture, 310, 298304.

Kohlmann, K., Kersten, P., Panicz, R., Memisc, D., \& Flajshans, M. (2010). Genetic variability and differentiation of wild and cultured tench population inferred from microsatellite loci. Rev Fish Biol Fish, 20, 279-288.

Kottelat, M., Whitten, A.J., Kartikasari, S.N., \& Wirjoatmodjo, S. (1993). Freshwater Fishes of Western Indonesia and Sulawesi. Jakarta: Periplus Edition (HK) Ltd.

Kurtz, J., Kalbe, M., Aeschlimann, P.B., Haberli, M.A., Wegner, K.M., Reusch, T.B.H., \& Milinski, M. (2004). Major histocompatibility complex diversity influences parasite resistance and innate immunity in sticklebacks. Proceedings of the Royal Society London B, 271(1535), 197-204.
Kurtz, J., Wegner, K.M., Kalbe, M., Reusch, T.B.H., Schaschi, H., Hasselquist, D., \& Milinski, M. (2006). MHC genes and oxidative stress in sticklebacks: an immuno-ecological approach. Proceedings of the Royal Society B, 273(1592), 1407-1414.

Kusbiyanto, Nuryanto, A., \& Soedibja, P.H.T. (2016). Detection of major histocompatibility complex class II gene on sowang giant gurami (Osphronemus goramy Lacepede, 1801) fingerling from one spawning. Jurnal Iktiologi Indonesia, 16(3), 279-288.

Kusmini, I.I., Hadie, L.E., Hadie, W., \& Kristanto, A.H. (2000). Karakterisasi dalam variasi fenotip beberapa ras ikan gurame (Osphronemus giant gourami) yang berpotensi dalam budidaya dengan analisis truss morphometrik. Prosiding Simposium Nasional Pengelolaan Pemulian dan Plasma Nutfah. Hlm 614 -620 .

Kussell, E. \& Leibler, S. (2005). Phenotypic diversity, population growth, and information influctuating environments. Science, 309, 275-278.

Lajbner, Z., Kohlmann, K., Linhart, O., \& Kotlik, P. (2010). Lack of reproductive isolation between the Western and Eastern pylogroups of the tench. Rev Fish Biol Fish, 20, 295-300.

Marin, S.A., Haye, P.A., Marchant, S., \& Winkler, F.M. (2007). Molecular marker used to analyze species-specific status in marine abalone with ambiguous morphology. Journal of Shellfish Research, 26(3), 833-837.

Mulyasari, Soesilowati, D.T., Kristanto, A.H., \& Kusmini, I.I. 2010. Karakteristik genetik enam populasi ikan nilem (Osteochilus hasselti) di Jawa Barat. Jurnal Riset Akuakultur, 5(2), 175-182.

Mayr, E. \& Ashlock, P.D. (1991). Principles of Systematic Zoology. $2^{\text {nd }}$ ed. New York: McGraw-Hill.

Nugroho, E. (2014). Genetic variability of giant gouramy strains revealed by random amplified polymorphism DNA. Indonesian Aquaculture Journal, 8(2), 107-111.

Nugroho, E., Subaja, J., Asih, S., \& Kurniasih, T. (2006). Evaluasi keragaman genetik ikan kancra dengan 
menggunakan marker MtDNA D-loop dan random amplified polymorphisms DNA (RAPD). Jurnal Riset Akuakultur, 1(2), 211-217.

Nuryanto, A. \& Susanto, A.H. (2010). Genetic variability of Polymesoda erosa population in the Segara Anakan Cilacap. Biotropia, 17(1), 22-30.

O'Brien, S. J. (1994). A role for molecular genetics in biological conservation. Proc Natl Acad Sci, 21, 5748-5755.

Penner, G.A., Bush, A., Wise, R., Kim, W., Domier, L., Kasha, K., Laroche, A., Scoles, G., Molnar, S.J., \& Fedak,G. (1993). Reproducibility of random amplified polymorphic DNA (RAPD) analysis among laboratories. Genome Res, 2, 341-345.

Rahman, Y. (2014). Struktur genetika populasi ikan gurami soang (Osphronemus gouramy Lac.) dari beberapa populasi di Pulau Jawa. Tesis. Purwokerto: Program Pascasarjana, Program Studi Biologi. Universitas Jenderal Soedirman.

Rakus, K.L., Wiegertjes, G.F., Jurecka, P., Walker, P.D., Pilarczyk, A., \& Irnazarov, I. (2009). Major histocompatibility (MH) class II B gene polymorphism influences resistance of common carp (Cyprinus carpio L.) Aquaculture, 288(1), $44-50$.

Reed, D.H. \& R. Frankham. (2003). Correlation between fitness and genetic diversity. Conservation Biology, 17(1), 230-237.

Rego, I., Martianez, A.S., Lez-Tizoa, A.G., Vieites, N.J., Leira, F., \& Meandez, J. (2002). PCR technique for identification of mussel species. J Agric Food Chem, 50, 1780-1784.

Roger, S.M., Gagnon, V., \& Bernatchez, L. (2005). Genetically based phenotypeenvironment association for swimming behavior in lake whitefish ecotypes (Coregonus clupeaformis Mitchill). Evolution, 56(11), 2322-2329.

Saanin, H. (1968). Taksonomi dan Kunci Identifikasi Ikan. Bandung: Binacipta.

Sari, A.K., Nuryanto, A., \& Pramono, H. (2014). Karakterisasi beberapa strain gurami Osphronemus goramy Lac. menggunakan marka RAPD. Scripta Biologica, 1(1), 113-116.
Schneider, S., Roessli, D., \& Excoffier, L. (2000). Arlequin, version 2.000. Geneva: University of Geneva.

Setijaningsih, L., Arifin, O.Z. \& Gustiano, R., (2007). Karakterisasi Tiga Strain Ikan Gurame (Osphronemus gouramy Lac.) Berdasarkan Metode Truss Morfometriks. Jurnal lktiologi Indonesia, 7(1), pp.23-30

Stepien C.A., Taylor C.D., \& Dabrowska, K.A. (2002). Genetic variability and phylogeographical patterns of a nonindigenous species invasion: a comparison of exotic vs. native zebra and quagga mussel populations. Journal of Evolutionary Biology, 15, 314-328.

Tarpy, D.R. (2003). Genetic diversity within honeybee colonies prevents severe infections and promotes colony growth. Proc R Soc Lond B, 270, 99-103.

Tao, W.J. \& Boulding, E.G. (2003). Association between nucleotide polymorphisms in candidate gene and growth Arctic charr (Salvelinus alpinus L.) Heredity, 91, 60-69.

Wegner, K.M., Kalbe, M., Rauch. G., Kurtz, J., Schaschl, H., \& Reusch, T.B.H. (2006). Genetic variation in MHC class II expression and interactions with MHC sequence polymorphism in three-spined sticklebacks. Molecular Ecology, 15(4), 1153-1164.

Walsh, P.S., Metzger, D.A. \& Higuchi, R. (1991). Chelex-100 as A Medium for Simple Extraction of DNA for PCR Based Typing from Forensic Material. Biotechniques, 10(4), 506-513.

Welsh, J., \& McClelland, M. (1990). Fingerprinting genomes using PCR with arbitrary primers. Nucleic Acids Res 18, 7213-7218.

Williams, J.G.K., Kubelik, A.R., Livak, K.J., Rafalski, J.A., \& Tingey, S.V. (1990). DNA polymorphisms amplified by arbitrary primers are useful as genetic markers. Nucleic Acids Res, 18, 6513-6535.

Whitham, T.G., Young, W.P., Maartinsen, G.D., Gehring, C.A., Schweitzer,J.A. Shuster, S.M., Wimp, G.M., Fischer, D.G., Bailey,J.K., Lindorrth, R.L., Woolbright, S., \& Kuske, C.R. (2003). Community and ecosystem genetics: a consequence of the extended phenotype. Ecology, 84(3), 559-573. 